\title{
Adaptation of Mycobacterium smegmatis to an Industrial Scale Medium and Isolation of the Mycobacterial PorinMspA
}

\author{
Sebastian O. Wendel ${ }^{1,2,3, *}$, Ayomi S. Perera ${ }^{2}$, Peter H. Pfromm ${ }^{3}$, Peter Czermak ${ }^{1}$ and \\ Stefan H. Bossmann", \\ ${ }^{1}$ University of Applied Sciences Giessen-Friedberg, Institute of Bioprocess Engineering and Pharmaceutical \\ Technology, Wiesenstrasse 14, 35390 Giessen, Germany \\ ${ }^{2}$ Kansas State University, Department of Chemistry, Manhattan, 213 CBC Building, KS 66506-0401, USA \\ ${ }^{3}$ Kansas State University, Department of Chemical Engineering, 1036 Durland Hall, Manhattan, KS 66506, USA
}

\begin{abstract}
The adaptation of the organism to a simple and cost-effective growth medium is mandatory in developing a process for large scale production of the octamericporinMspA, which is isolated from Mycobacterium smegmatis. A fermentation optimization with the minimal nutrients required for growth has been performed. During the fermentation, the iron- and ammonium chloride concentrations in the medium were varied to determine their impact on the observed growth rates and cell mass yields. Common antibiotics to control contamination were eliminated in favor of copper sulfate to reduce costs. MspA has been successfully isolated from the harvested $M$. smegmatisusing aqueous nOPOE (noctyloligooxyethylene) at $65^{\circ} \mathrm{C}$. Because of the extraordinary stability of $\mathrm{MspA}$, it is possible to denature and precipitate virtually all other proteins and contaminants by following this approach. To further purify the product, acetone is used for precipitation. Gel electrophoresis confirmed the presence and purity of MspA. A maximum of $840 \mu \mathrm{g}$ (via Bradford assay) of pure MspA per liter of the optimized simple growth medium has been obtained. This is a $40 \%$ increase with respect to the previously reported culture medium for MspA.
\end{abstract}

Keywords: Medium, optimization, Mycobacterium, smegmatis, MspA, protein extraction.

\section{INTRODUCTION}

MspA is an octamericporin in the outer membrane of $M$. smegmatis [1-3].The inner pore of MspA is the major general diffusion pathway for the organism and provides a passage for hydrophilic solutes. The crystal structure of MspA shows the assembly of eight monomers to a goblet shaped pore [4]. Each monomer contains two consecutive 16stranded $\beta$-Barrels with hydrophobic outer surfaces (the socalled constriction zone, which is marked with an arrow in Fig. 1).

These surfaces are thought to induce the anchorage of the porin in the lipid bi-layer [1]. Infrared and circular dichroism spectroscopy revealed that heating to $92^{\circ} \mathrm{C}$ and $112^{\circ} \mathrm{C}$ is required to dissociate the MspAoctamer and to unfold the $\beta$ sheet domain in the monomer, respectively [6]. The thermal stability of the MspA octamer exceeds even the remarkable stability of the porins of Gram-negative bacteria for every condition tested and is not diminished in the presence of $2 \%$ $\mathrm{SDS}$ or within the $\mathrm{pH}$-range from 2 to 11 . Due to its superior

*Address correspondence to these authors at the Kansas State University, Department of Chemistry, Manhattan, 213 CBC Building, KS 66506-0401, USA; Tel: 785-532-6817; Fax: 785-532-6666; E-mails: sbossman@ksu.edu; sw87@k-state.edu stability, anisotropy, and the ability to form a hydrophilic homopore, MspA is suited for many and surprisingly different applications. It has been deposited on HOPG-surfaces to form nanopores [5] and complex protein-networks [7], and letter- or star-shaped microstructures when deposited together with PMMA [8].MspA reconstitutes in artificial $[9,10]$ and natural cell membranes [11], as well as polymerlayers [12]. It forms cation-selective ion channels that show voltage gating [12]. The probably most intriguing discovery is that MspA can freely stand with its axis of symmetry perpendicular to a MICA surface without the support of a self assembled monolayer or polymer-layer [13]. A self assembled monolayer is a layer of self-positioning molecules connected to a surface.

Due to its versatility, MspA represents a high-value product (currently $\$ 35$ per $1 \mu \mathrm{g}$ of purified protein). Our goal is the efficient production of MspA from minimal medium and its efficient purification, so that a market price of less than $\$ 10$ per $1 \mu \mathrm{g}$ could be reached. This would permit the broad application of MspA as a biological nanotool. One possible applicationmay be the use of MspA as a template for copper nanoparticles in the research for nano-sized digital storage devices [10]. Furthermore MspAmay be applied in the investigation of mycobacterial channel blocking agents,which represent a new strategy in the treatment of 


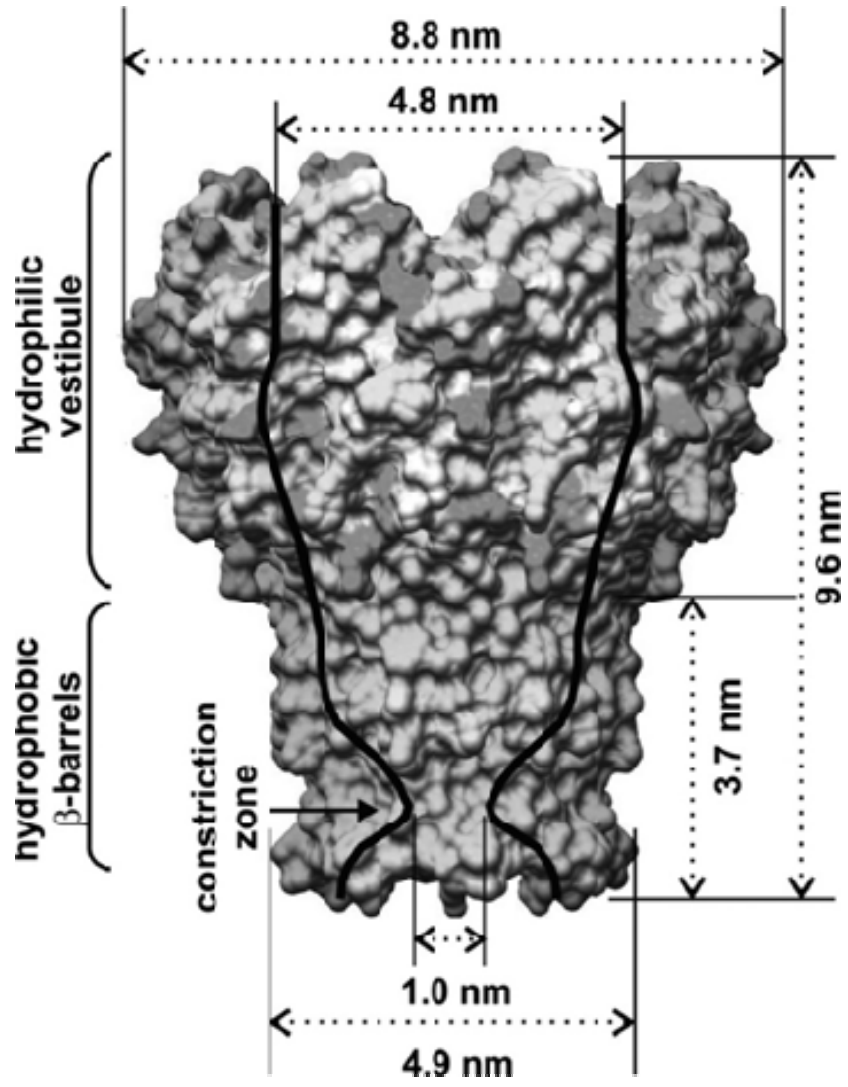

Fig. (1). Crystal Structure of MspA of M. smegmatis.Surface representation: light/dark gray: hydrophilic amino acids; mid-gray: hydrophobic amino acids. Note the constriction zone consisting of only hydrophobic amino acids.

With permission from the Journal of Physical Chemistry C, copyright American Chemical Society, 2010. ${ }^{5)}$

tuberculosis and the supply of M. tuberculosis with hydrophilic nutrients [14].The Niederweis group at the University of Alabama at Birmingham has developed a method to selectively extract Mspporins out of M. smegmatis grown in Middlebrook 7H9 medium [15]. This procedure exploits the extreme thermal stability of MspA by heating M. smegmatis cells to $100{ }^{\circ} \mathrm{C}$ in the presence of $0.5 \%$ of the non-ionic detergent $n$-octylpolyoxyethylene and yields mainly Mspporins with very little contamination by other proteins [15]. The detergent extracts of the strain M. smegmatis ML10 $(\triangle \mathrm{MspA} \triangle \mathrm{MspC})$ do not show any porin band in Coomassiestained protein gels. A background expression of Mspporins is still detectable in immunoblots using an Msp-specific antiserum [15].It will be demonstrated here that efficient production of MspA can be attained in a relatively simple and inexpensive medium, with the total cost for the fermentation medium estimated at $\$ 20$ per $\mu \mathrm{g}$ purified protein and with a productivity of $12 \mu \mathrm{g}$ protein per liter of medium and hour.

\section{MATERIALS \& METHODOLOGY}

\section{Materials}

- SDS (Sodium Dodecyl Sulfate)

- Centrifuge Thermo Scientific Sorvall Legend RT+, Asheville, NC
- Gel electrophoresis equipment: Power Pac Basic, Mini PROTEAN Tetra cell, Bio Rad, Hercules, CA

- Gel electrophoresis chemicals: TEMED (Tetramethylethylenediamine), APS (Ammonium persulfate), Acrylamide / N,N'-Methylenbisacrylamide solution (30:1), Bio Rad, Hercules, CA

- Gel buffer 3x concentrated: 11 distilled water, 3M TRIS (tris-hydroxymethyl-aminomethane), $0.3 \mathrm{w} \% \mathrm{SDS}, \mathrm{pH}$ 8.45 adjusted with $\mathrm{NaOH} / \mathrm{HCl}$

- Cathode Buffer 10x concentrated: 1M TRIS, 1M Tricine(N-(2-Hydroxy-1,1-

bis(hydroxymethyl)ethyl)glycine), 1w\% SDS, $\mathrm{pH} 8.25$ adjusted with $\mathrm{NaOH} / \mathrm{HCl}$

- Anode Buffer 10x concentrated: 1M TRIS, pH8.9 adjusted with $\mathrm{NaOH} / \mathrm{HCl}$

- Controlled environment incubation shaker, New Brunswick Scientific Co. Inc, New Brunswick, NJ

- $14 \mathrm{ml}$ polystyrene round bottom tube Falcon, Becton Dickinson Labware, Franklin Lakes NJ

- KIMAX 21 culture flasks, $125 \mathrm{ml}$ culture flasks, KIMAX, Janesville WI

- Phosphate buffered saline (PBS buffer) 10x concentrated: 11 distilled water, $1.36 \mathrm{M} \mathrm{NaCl}, 45 \mathrm{mM} \mathrm{KCl}$, $100 \mathrm{mM} \mathrm{Na}_{2} \mathrm{HPO}_{4}, 18 \mathrm{mM} \mathrm{K \textrm {K } _ { 2 }} \mathrm{PO}_{4}, \mathrm{pH} 7.4$ adjusted with $\mathrm{NaOH} / \mathrm{HCl}$

- PEN buffer $3 \mathrm{x}$ concentrated: $750 \mathrm{ml}$ distilled water, $300 \mathrm{mM} \mathrm{Na}_{2} \mathrm{HPO}_{4}, 0,3 \mathrm{mM} \mathrm{Na}_{2}$-EDTA, $450 \mathrm{mMNaCl}$

- The $\mathrm{mc}^{2} 155$ strain of Mycobacterium smegmatis was used in all experiments.

The composition of the different types of media is shown in Table 1.

The composition of the 7H9 Middlebrook is shown in Table 2. 4ml Glycerol, $2 \mathrm{ml}$ Tween 80, 300 $\mu 1$ Hygromycinwere added additionally.

All chemicals mentioned are purchased from Sigma Aldrich if not otherwise noted.

\section{Medium Preparation}

All chemicals were purchased from Sigma-Aldrich. A 11 Nalgene bottle is filled with $400 \mathrm{ml}$ distilled $\mathrm{H}_{2} \mathrm{O}$. Potassium phosphate, sodium chloride, sodium nitrate and ferric chloride were added (amounts see Table 2) and the $\mathrm{pH}$ is adjusted to 7.2 with hydrochloric acid. A second 11 Nalgene bottle is filled with $560 \mathrm{ml} \mathrm{H}_{2} \mathrm{O}$ and Zinc Chloride and Glucose were added and $\mathrm{pH}$ is adjusted to $\mathrm{pH} 7.2(\mathrm{HCl})$. Both bottles were autoclaved and the contents were then combined. $15 \mathrm{ml}$ mineral solution, $2 \mathrm{ml}$ Tween 80 , and $2 \mathrm{ml}$ of a $0.01 \%$ Copper(II) sulfate-Malachite green solution were added.

\section{Growth Cycle}

The Growth cycle is structured in three steps: Maintenance-, medium size and large cultures. To start a new maintenance culture, $4.5 \mathrm{ml}$ medium and $0.5 \mathrm{ml}$ inoculum were combined in a $14 \mathrm{ml}$ polystyrene round bottom Falcon tube 
Table 1. Different Media and Their Components

\begin{tabular}{|c|c|c|c|}
\hline Chemicals & Minimal Medium "First Approach" & $\underline{\text { Iron Impact Medium }}$ & Nitrogen Source Medium \\
\hline distilled water & $960 \mathrm{ml}$ & $960 \mathrm{ml}$ & $960 \mathrm{ml}$ \\
\hline glucose & $20.0 \mathrm{~g}$ & $20.0 \mathrm{~g}$ & $20.0 \mathrm{~g}$ \\
\hline sodium nitrate & $0.5 \mathrm{~g}$ & $0.5 \mathrm{~g}$ & $0.5 \mathrm{~g}$ \\
\hline monobasic sodium phosphate & $1.0 \mathrm{~g}$ & $1.0 \mathrm{~g}$ & $1.0 \mathrm{~g}$ \\
\hline sodium chloride & $1.2 \mathrm{~g}$ & $1.2 \mathrm{~g}$ & $1.2 \mathrm{~g}$ \\
\hline zinc chloride & $0.05 \mathrm{~g}$ & $0.05 \mathrm{~g}$ & $0.05 \mathrm{~g}$ \\
\hline Copper Complex (to replace the antibiotic hygromycin) & $2.0 \mathrm{ml}$ & $2.0 \mathrm{ml}$ & $2.0 \mathrm{ml}$ \\
\hline
\end{tabular}

allowing 2-3 days of growth time, using the New Brunswick Scientific PsycroTherm Incubator Shaker at $75 \mathrm{rpm}, 37^{\circ} \mathrm{C}$. The medium cultures grow in KIMAX $125 \mathrm{ml}$ shaking flasks. A sterile flask was under filled with $36 \mathrm{ml}$ medium on the clean bench and inoculated with $4 \mathrm{ml}$ cell suspension from a maintenance culture without further shaking. The flask was covered with metal lids and placed in an orbital shaker for two days.

Table 2. 7H9 Middlebrook Medium Composition (Fluka Analytical)

\begin{tabular}{|c|}
\hline $0.5 \mathrm{~g} / 1$ Ammonium sulfate \\
\hline $2.5 \mathrm{~g} / 1$ Disodium phosphate \\
\hline $1 \mathrm{~g} / 1 \mathrm{Monopotassium}$ phosphate \\
\hline $0.1 \mathrm{~g} / 1$ Sodium chloride \\
\hline $0.05 \mathrm{~g} / 1$ Magnesium sulfate \\
\hline $0.0005 \mathrm{~g} / 1$ Calcium chloride \\
\hline $0.001 \mathrm{~g} / 1$ Zinc sulfate \\
\hline $0.001 \mathrm{~g} / 1$ Copper sulfate \\
\hline $0.04 \mathrm{~g} / 1 \mathrm{Ferric}$ ammonium citrate \\
\hline $0.5 \mathrm{~g} / 1 \mathrm{~L}-$ Glutamic acid \\
\hline $0.001 \mathrm{~g} / 1$ Pyridoxine \\
\hline $0.0005 \mathrm{~g} / 1$ Biotin \\
\hline
\end{tabular}

The growth of the large cultures was carried out in 2000ml KIMAX shaking flasks. The flasks were filled with $960 \mathrm{ml}$ medium and inoculated with a complete medium size culture,bringing the total volume in the flask to $1000 \mathrm{ml}$. The flasks were sealed with aluminum foil to prevent contamination and placed in the shaker for 3-5 days (see medium size cultures for conditions).

\section{MspA Purification Process}

A large culture (about 1 l) was centrifuged for one hour at $3,700 \mathrm{~g}$ using $800 \mathrm{~g}$ capacity bottles. The supernatant was decanted while the cells were suspended in 50ml PBS buffer and the resulting suspension was divided in $50 \mathrm{ml}$ conical tubes for centrifugation at $10,000 \mathrm{~g}$ for one hour using a fixed rotor. $10 \mathrm{ml}$ PEN buffer was added to the cell pellet to disperse the cells in the $50 \mathrm{ml}$ conical tubes after the supernatant was removed. The dispersed cells are collected in a $200 \mathrm{ml}$ Nalgene bottle and kept at $60-65^{\circ} \mathrm{C}$ in a water bath under agitation (magnetic stir bar, 200rpm, $2 \mathrm{~cm}$ length). The temperature range is very important for optimum results. $10 \mu \mathrm{l}$ nOPOE was added and the cell suspension was kept in the water bath for one hour. The suspension was then transferred into a $50 \mathrm{ml}$ conical tube and again centrifuged at $10,000 \mathrm{~g}$ for one hour. A $50 \mathrm{ml}$ conical tube with water was used as a counterweight. The supernatant was collected in a $100 \mathrm{ml}$ nalgene bottle and $10 \mathrm{ml}$ pre-cooled acetone $\left(-20^{\circ} \mathrm{C}\right)$ was added before storing the bottle in a freezer $\left(-20^{\circ} \mathrm{C}\right)$ overnight. After centrifuging the cold suspension for 30 minutes at $10,000 \mathrm{~g}$ the supernatant was discarded and the cell pellets were dissolved in $10 \mathrm{ml}$ PBS buffer before ultrafiltration (Millipore Centrifugal Filter Units MWCO 3000 Dalton, Millipore, Billerica, MA). Centrifuging at $10000 \mathrm{~g}$ for 30 minutes concentrates the product further.

\section{Product Analysis: Gel Electrophoresis}

To prepare an acryl amide separation gel for the gel electrophoresis $3.30 \mathrm{ml}$ acryl amide-BIS solution (30:1) was added into a $15 \mathrm{ml}$ conical tube. Also $4.50 \mathrm{ml}$ gel buffer, $3.30 \mathrm{ml}$ bidest. $\mathrm{H}_{2} \mathrm{O}$ and $2.25 \mathrm{ml}$ glycerol were added and mixed well. Next, $0.015 \mathrm{ml}$ TEMED and $0.135 \mathrm{ml} \mathrm{10 \% APS}$ were added and the solution was filled into the glass chamber and the top was covered with a layer of water. For the collection gel, $0.80 \mathrm{ml}$ acrylamide-BIS $(30: 1), 2.60 \mathrm{ml}$ gel buffer and $4.20 \mathrm{ml}$ bidistilled $\mathrm{H}_{2} \mathrm{O}$ were added to a $15 \mathrm{ml}$ conical tube. Then 0.015 TEMED and $0.16010 \%$ APS were added and mixed. The covering water from the separation 
gel was removed and the collection gel solution was added. A comb is placed for pocket formation.

The gel was placed after 30 minutes in the electrophoresis cartridge and the combwas removed. After loading the samples and molecular marker into pockets, the electrophoresis process was started using $125 \mathrm{~V}$ constant voltage.

Electric power was supplied by BioRadPowerPac Basic and the gel cartridge was a BioRad Mini-Protean Tetra Cell.

The method was adapted from references [16] and [17].

\section{HPLC}

Protein-containing solutions were analyzed using a Gilson/Hewlett Packard HPLC workstation (Gilson 322 pump, Gilson, Middleton, WI, Hewlett-Packard series 1100 detector, Agilent, Santa Clara, CA) employing a POROS HQ anion exchange column (4.6mm diameter, Applied Biosystems, Carlsbad, CA). The mobile phase consisted of a gradient of two buffers (5mM SDS, composition and 5mM SDS, 1M $\mathrm{NaCl}$, composition). The HPLC procedure has been adapted from reference 14 . Flow rate was $0.50 \mathrm{ml} / \mathrm{min}$ and the injection volume was $50 \mu 1$.

\section{Sterilization}

Autoclaving (Yamato Sterilizer SM 200, Santa Clara, CA 95050, USA) $110^{\circ} \mathrm{C}, 30 \mathrm{~min}$ holding time, was used for sterilization. $70 \mathrm{vol} \%$ ethanol in distilled water was used to sterilize equipment that could not be autoclaved.

\section{RESULTS AND DISCUSSION}

\section{Growth Experiments}

$M$. smegmatis can be grown efficiently in a simple and well-defined medium as shown in Fig. 2). The effectiveness of the copper complex in suppressing competing microorganisms was demonstrated by the fact that none of the fermentations were contaminated without any great measures to maintain sterility.

The experiment was stopped after 70 hours of total growth-time with a maximum optical density of 0.84 . A wet cell-mass result of $2.0 \mathrm{~g} \pm 0.1 \mathrm{~g}$ was harvested which equals a yield of $10 \mathrm{wt} \%$ on the carbohydrates in the medium.

To analyze the impact of iron on the growth of $M$. smegmatisa second approach with various iron contents was started. Three cultures with an addition of 20, 50 and $100 \mathrm{mg}$ ferric chloride per liter were investigated. The experiment was stopped after 40 hours of total growth-time with a maximum optical density of 0.96 . Again a cell-mass result of $2.0 \mathrm{~g} \pm 0.1 \mathrm{~g}$ was achieved.

Surprisingly, no conclusive influence of iron in the range tested on the growth of M. smegmatiswas observed (Fig. 3) although iron has been reported to be of some importance in mycobacterial protein synthesis [19]. The absence of a consistent impact of iron concentration in the range tested points perhaps towards a very effective collection mechanism of iron in mycobacteria [20].

The third approach focuses on the nitrogen source. Besides sodium nitrate, we introduced ammonium chloride as a second nitrogen source to further promote growth in our cultures (Fig. 4). The attempt led to extended growth of the $M$. smegmatis cultures. Maximum growth times, as well as maximum OD600 and cell mass yield were increased:

The cell mass harvested is shown in Table $\mathbf{3}$, along with the initial ammonium chloride concentration.

Therefore the maximum cell mass yield relative to the carbon source was $15 \mathrm{wt} \%$.

The addition of a different nitrogen source shows a major impact on growth and yield of $M$. smegmatis. The addition of $0.5 \mathrm{~g} \mathrm{NH}_{4} \mathrm{Cl}$ led to an increased biomass yield of $35 \%$ in comparison to the first approach. These results were exceeded by the addition of $1.0 \mathrm{~g} \mathrm{NH}_{4} \mathrm{Cl}$. Here the comparison with the first approach results in a $50 \%$ cell mass gain. However, the growth did not reach the level discussed above when $2.0 \mathrm{~g} \mathrm{NH}_{4} \mathrm{Cl}$ were added. Apparently a somewhat toxic level was reached, resulting in partial growth inhibition. The harvested cell mass of $M$. smegmatis was decreased to the results of the basic approach and its growth showed only minor improvements.

The same trend as above has also been observed in the carbon-conversion yield to cell mass. The yield relative to



Fig. (2). Standard recipe for minimal medium, all cultures grown under the same conditions $\left(37^{\circ} \mathrm{C}, 75 \mathrm{rpm}\right) .20 \mathrm{~g}$ Glucose, $0.5 \mathrm{~g}$ sodium nitrate, $1 \mathrm{~g}$ monobasic sodium phosphate, $1.2 \mathrm{~g}$ sodium chloride, $0.05 \mathrm{~g}$ zinc chloride, $15 \mathrm{ml}$ liquid minerals, $2 \mathrm{ml}$ Tween $80,2 \mathrm{ml}$ copper complex solution, line drawn to guide the eye only. 


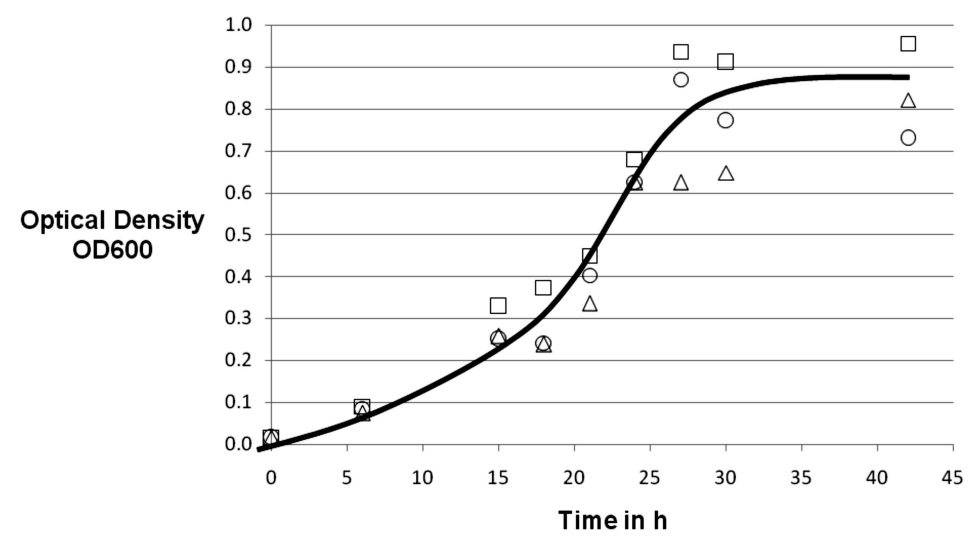

Fig. (3). Growth experiment with various iron contents. $20 \mathrm{~g}$ Glucose, $0.5 \mathrm{~g}$ sodium nitrate, $1 \mathrm{~g}$ monobasic sodium phosphate, $1.2 \mathrm{~g}$ sodium chloride, $0.05 \mathrm{~g}$ zinc chloride, $15 \mathrm{ml}$ liquid minerals, $2 \mathrm{ml}$ Tween $80,2 \mathrm{ml}$ copper complex solution. $\triangle: 20 \mathrm{mg} \mathrm{FeCl}_{3} / 1 ; \square: 50 \mathrm{mg} \mathrm{FeCl} 3 / 1 ; \mathrm{O}$ : $100 \mathrm{mg} \mathrm{FeCl}_{3} / 1$, line drawn to guide the eye only.

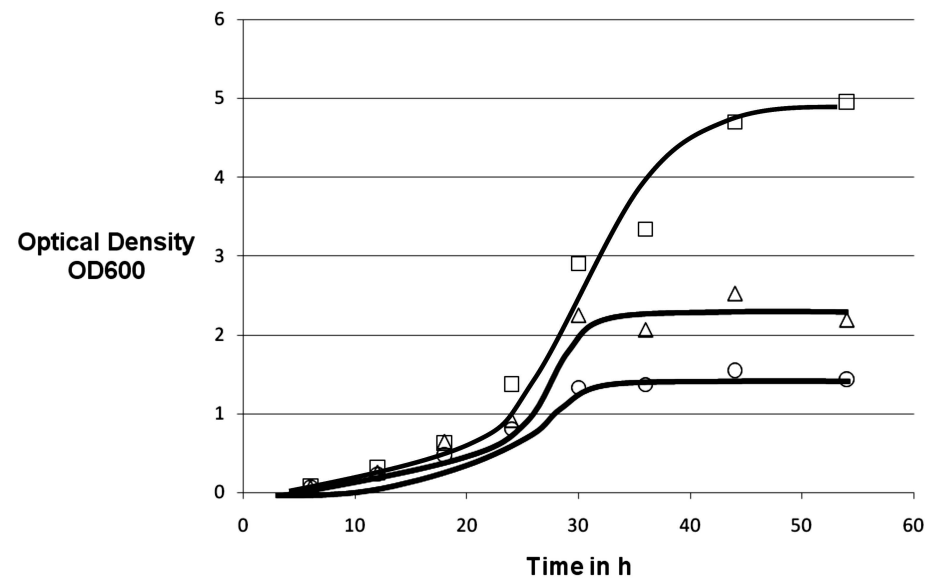

Fig. (4). Growth experiment with various amounts of ammonium chloride as secondary nitrogen source. $20 \mathrm{~g}$ Glucose, $0.5 \mathrm{~g}$ sodium nitrate, $1 \mathrm{~g}$ monobasic sodium phosphate, $1.2 \mathrm{~g}$ sodium chloride, $0.05 \mathrm{~g}$ zinc chloride, $15 \mathrm{ml}$ liquid minerals, $2 \mathrm{ml}$ Tween 80 , $2 \mathrm{ml}$ copper complex solution O: 2g/l Ammonium Chloride; $\square$ : 1g/l Ammonium Chloride; $\triangle:$ 0.5g/l Ammonium Chloride, line drawn to guide the eye only.

Table 3. Obtained Cell-Mass for the Additional Nitrogen Source Experiment

\begin{tabular}{|c|c|c|c|}
\hline Amount of Ammonium Chloride in g/l & $\mathbf{0 . 5}$ & $\mathbf{1}$ & $\mathbf{2}$ \\
\hline \hline Cell mass in $\mathrm{g}$ & 2.7 & 3 & 2.1 \\
\hline
\end{tabular}

the amount of the consumed carbohydrate substrate was increased from $10 \mathrm{wt} \%$ in the reference experiments and the iron supplement experiments to approximately $15 \mathrm{wt} \%$.

\section{MspA Extraction and Analysis}

The extracted product MspA was analyzed in three steps. The first step, gel electrophoresis, shows the purity of the product and verifies the presence of MspA. Our results were identical with earlier findings by Niederweis et al. $[6,15]$. Fig. (5) shows the MspA band on the left side and the molecular marker on the right. The marker indicates a size of approximately $160 \mathrm{kD}$ and the single band present demonstrates the high purity of the extraction product. However the slight haze down the left lane indicates that there were likely some denatured protein fragments in the sample. Fig. (5) also shows the HPLC analysis of our extraction product. Two peaks at retention times of about 14 and 25 minutes are clearly discernible. Both fractions were collected and a gel electrophoresis experiment with the second fraction shows the presence of MspA. Comparison with the literature indicates that the first peak is $\mathrm{MspC}$, a porin quite similar to MspA regarding size and structure [15].

The results of the Bradford assay show a concentration of about $600 \mathrm{mg}$ protein per $\mathrm{ml}( \pm 5.6 \%)$, at a yield of $1.4 \mathrm{ml}$ per extraction. Fig. (6) shows the calibration standard for the assay.

Assay

The Bradford assay was carried out according to reference 21.See Fig. (6) for the calibration results. 


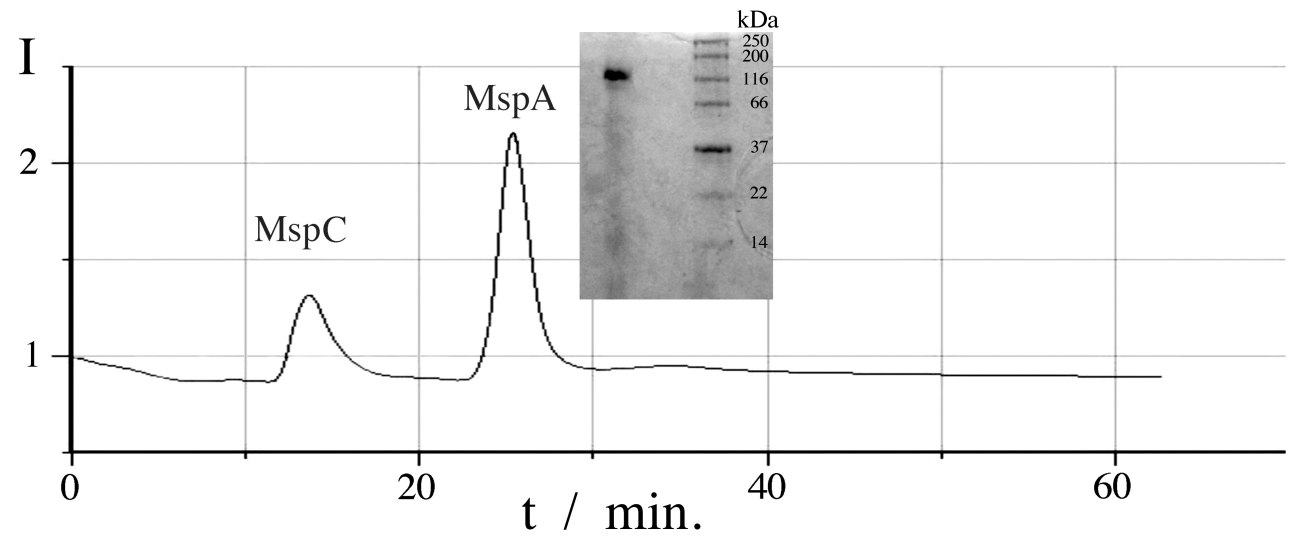

Fig. (5). HPLC analysis of an extraction sample from M. smegmatis and gel from MspA analysis with molecular marker.

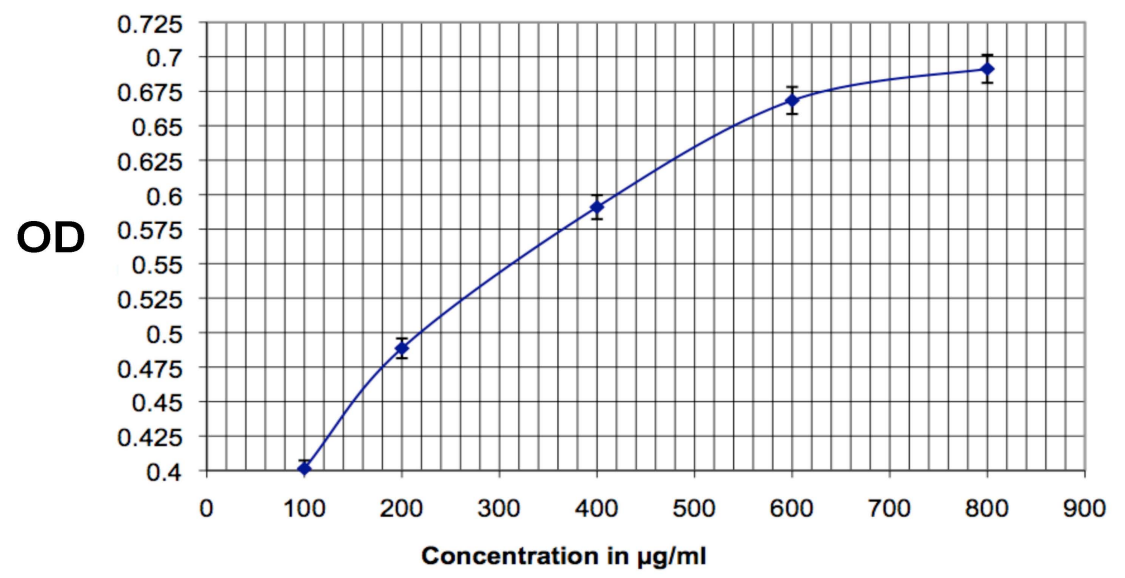

Fig. (6). Calibration for the Bradford assay to determine the protein concentration in the extracted product. Optical Density (OD) is measured at $595 \mathrm{~nm}$, pathlength: $1 \mathrm{~cm}$.

\section{CONCLUSION}

In the experiments described above, we show that $M$. smegmatiscan be cultivated in a medium providing only very basic nutrients and that the cell mass yields can compete with the results obtained from the standard medium (7H9 Middlebrook). This new method results not only in high yields and a pure product (the high-value porinMspA), but also a low risk of contamination. No contaminations were detected during the whole series of experiments described here. As a result from using the less expensive growth medium and the enhanced yield of purified MspA (up by $40 \%$ compared to $7 \mathrm{H} 9$ ), we estimate that we were able to lower the price of MspA to approx. $\$ 20$ per $1 \mu \mathrm{g}$ of purified protein. A next step could be the investigation of the impact of agitation and aeration on the growth of $M$. smegmatis for scaleup to a multi-liter size bioreactor. Furthermore a possible replacement of glucose as carbon source by an industrial waste product, for example molasses, would be interesting to further reduce costs.

\section{CONFLICT OF INTEREST}

The authors confirm that this article content has no conflicts of interest.

\section{ACKNOWLEDGEMENTS}

This material is based upon work supported by the National Science Foundation under Award No. EPS-0903806 and matching support from the State of Kansas through Kansas Technology Enterprise Corporation. The authors thank Dr. Michael Niederweis, Department of Microbiology, University of Alabama at Birmingham for generously providing the mc2 155 strain of Mycobacterium smegmatis.

\section{REFERENCES}

[1] Stahl C, Kubetzko S, Kaps I, Seeber S, Engelhardt H, Niederweis M. MspA provides the main hydrophilic pathway through the cell wall of Mycobacterium smegmatis. Mol Microbiol 2001; 40: 45164 (Authors' correction appeared in Mol. Microbiol. 457, 1509).

[2] Mailaender C, Reiling N, Engelhardt H, Bossmann S, Ehlers S, Niederweis M. The MspA porin promotes growth and increases antibiotic susceptibility of both Mycobacterium bovis BCG and Mycobacterium tuberculosis. Microbiology 2004; 150: 853-64.

[3] Niederweis M, Bossmann SH. Nanostructuring at surfaces using proteins. Encyclopedia Nanosci Nanotechnol 2004; 7: 851-67.

[4] Faller M, Niederweis M, Schulz GE. The structure of a mycobacterial outer-membrane channel. Science 2004; 303: 1189-92.

[5] Gamage P, Basel MT, Lovell K, et al. Poly-n-isopropylacrylamide/acrylic acid copolymers for the generation of nanostructures on mica surfaces and as hydrophobic host systems for the Porinmspa from mycobacterium smegmatis. J Phys Chem 2009; C113: 16485-94. 
[6] Heinz C, Engelhardt H, Niederweis M. The core of the tetrameric mycobacterial porinmspa is an extremely stable $\beta$-sheet domain. $\mathrm{J}$ Biol Chem 2003; 278: 8678-85.

[7] Niederweis M, Heinz C, Janik K, Bossmann SH. Nanostructuring by deposition of protein channels formed on carbon surfaces. Nano Lett 2002; 2: 1263-8.

[8] Niederweis M, Heinz C, Janik K, Bossmann SH. Nanostructuring of carbon surfaces by deposition of a channel-forming protein and subsequent polymerization of methyl methacrylate prepolymers. Nano Lett 2001; 1: 169-74.

[9] Wörner M, Niebler S, Gogritchiani E, et al. Nanoarray-surfaces by reconstitution of the porinmspa into stabilized long-chain-lipidmonolayers at a gold-surface. Electroanalysis 2006; 19-20: 185970 .

[10] Wörner M, Lioubashevski O, Niebler S, et al. Characterization of Nanostructured-Surfaces Generated by Reconstitution of the porinmspa from $m$. smegmatis into stabilized long-chainmonolayers at gold-electrodes. Small 2007; 3: 1084-97.

[11] Bossmann SH, Janik K, Pokhrel MR, Heinz C, Niederweis M. Reconstitution of a porin from Mycobacterium smegmatis at HOPG covered with hydrophobic host layers. Surf Interface Anal 2004; 36: $127-34$.

[12] Engelhardt H, Heinz C, Niederweis M. A tetramericporin limits the cell wall permeability of Mycobacterium smegmatis. J Biol Chem 2002; 277 : 37567-72.
[13] Basel MT, Dani RK, Kang M, et al. Direct observation of gold nanoparticle assemblies with the porinmspa on mica. ACS Nano 2009; 3: 462-6.

[14] Perera AS, Wang H, Basel, MT, et al. Channel blocking revisited langmuir 2013; 29: 308-15.

[15] Heinz C, Niederweis M. Selective extraction and purification of a mycobacterial outer membrane protein. Anal Biochem 2000; 285: $113-20$

[16] von Jagow G, Link TA, Schaegger H. Purification strategies for membrane proteins. Pract Guide Membr Protein Purif USA: Elsevier 1994; pp. 3-21.

[17] Baltz EH, Davies E, Demain AL. Manual Of Industrial Microbiology And Biotechnology. $3^{\text {rd }}$ ed. Washington D.C. Am Soc Microbiol, 2010; p. 766.

[18] Storhas W. Bioverfahrensentwicklung. Weinheim:Wiley/VCH, Weinheim. 2003; p. 400

[19] Bacon J, Dover LG, Hatch KA, et al. Lipid composition and transcriptional response of Mycobacterium tuberculosis grown under iron -limitation in continuous culture: identification of a novel wax ester. Microbiology 2007; 153: 1435-44.

[20] Jones CM, Niederweis M. Role of porins in iron uptake by $\mathrm{Myco-}$ bacterium smegmatis. J Bacteriol 2010; 192: 6411-7.

[21] Bradford M. A rapid and sensitive method for the quantitation of microgram quantities of protein utilizing the principle of proteindye binding. Anal Biochem1976; 72: 248-54.

(C) Wendel et al.; Licensee Bentham Open.

This is an open access article licensed under the terms of the Creative Commons Attribution Non-Commercial License (http://creativecommons.org/licenses/by-nc/3.0/) which permits unrestricted, non-commercial use, distribution and reproduction in any medium, provided the work is properly cited. 